Helen Nurhayati, M. Gafar Yoedtadi: Konstruksi Berita Covid-19 di Kompas.com dan Tribunnews.com

\title{
Konstruksi Berita Covid-19 di Kompas.com dan Tribunnews.com
}

\author{
Helen Nur Hayati, M. Gafar Yoedtadi \\ helennurhayatii@gmail.com,gafary@fikom.untar.ac.id \\ Fakultas Ilmu Komunikasi Universitas Tarumanagara
}

\begin{abstract}
This study discusses the analysis framing of Covid-19 news on the March 2, 2020 edition in the media of Kompas.com and Tribunnews.com. The reason the researchers chose Kompas.com and Tribunnews.com was because based on the Alexa.com, both news portals had the highest number of visitors in Indonesia. In analyzing this the researcher used Robert $N$. Entman's framing analysis method with qualitative research methods. Researchers conducted this research to study how to frame the two media in the reporting of the Covid-19 outbreak in Indonesia. From the research results obtained in Tribunnews.com media, it does not favor covid-19 patients and some articles from Tribunnews are also inaccurate, there are other things from Kompas.com media about covid-19 cases in Indonesia, and some news articles from Kompas. com is also very educational for the readers.
\end{abstract}

Keywords: framing analysis, construction news, covid-19

\begin{abstract}
Abstrak
Penelitian ini membahas tentang analisis framing berita Covid-19 pada edisi 2 Maret 2020 dalam portal media Kompas dan Tribunnews. Alasan peneliti memilih Kompas.com dan juga Tribunnews.com karena berdasarkan situs Alexa.com, kedua portal berita tersebut memiliki jumlah pengunjung pembaca terbanyak di Indonesia. Peneliti juga memilih topik Covid-19 dikarenakan kasus ini berkaitan dengan jurnalisme kesehatan di mana seorang jurnalis kesehatan harus efektif, akurat, simbang dalam hal sumber informasi,konsisten dan harus menghasilkan perubahan. Penelitian ini menggunakan pendekatan penelitian kualitatif dan analisis framing model Robert N. Entrman. Penelitian ini bertujuan untuk mengetahui bagaimana framing yang dilakukan kedua media tersebut dalam pemberitaan kasus wabah Covid-19 di Indonesia. Hasil penelitian menunjukkan bahwa berita Tribunnews.com tidak berempati terhadap pasien covid-19 dan fakta yang diungkapkan kerap kali tidak akurat. Sementara berita Kompas.com melihat persoalan Covid-19 dari sudut pandang pemerintah yang selalu memberikan himbauan kepada masyarakat. Berita Kompas.com juga melakukan edukasi bagi pembacanya.
\end{abstract}

Kata Kunci: analisis framing, konstruksi berita, covid-19

\section{Pendahuluan}

Kesehatan adalah isu yang tidak biasa. Kesehatan tak hanya terkait dengan persoalan penyebaran penyakit dan pengobatannya untuk masyarakat, namun juga terkait dengan kebijakan lintas sektoral. Kaitan yang luas ini membuat telaah, analisis, dan pelaporan mengenai isu kesehatan tidak bisa dilihat secara keseluruhan. Kebijakan kesehatan disuatu negara misalnya, berhubungan erat dengan berbagai macam aturan yang memberi ruang pada tenaga kesehatan, teknologi kedokteran, industri farmasi, serta jangkauan upaya pencegahan dan pengobatan secara merata (Prakarsa, 2016).

Dalam memberitakan isu kesehatan tidak membutuhkan latar belakang kedokteran maupun keperawatan, namun, pengetahuan yang memadai tentang medis 
akan sangat membantu penulisan jurnalistik dan sangat berguna juga untuk masyarakat tahu pentingnya masalah kesehatan dan cara menanganinya. Hal ini menyadari begitu kuatnya peran media massa dalam pembentukkan opini publik, sehingga media dituntut mempunyai hakikat dalam menjalankan fungsi media itu sendiri (Prakarsa, 2016).

Fungsi media massa tidak dapat dilepaskan dalam komunikasi kesehatan. Media massa dapat melakukan edukasi dan promosi kesehatan kepada masyarakat. Selebihnya media massa dapat membantu mitigasi ketika terjadi bencana kesehatan (WHO, 2005). Dengan kemampuan dan daya jangkau yang luas dalam mendistribusikan informasi, media massa dapat membantu memberi peringatan dan pengetahuan kepada masyarakat agar terhindar dari wabah penyakit (Hooker et al, 2012). Namun sebaliknya, media massa dapat pula memperkeruh situasi krisis kesehatan ketika berita yang dipublikasikan lebih menonjolkan sensasi dan rasa takut kepada masyarakat (Klemm et al., 2016).

Pada awal tahun 2020, masyarakat dunia digemparkan dengan penemuan virus baru yaitu virus Corona atau dikenal dengan nama penyakit Covid-19 (Coronavirus Disease 2019). Virus ini pertama kali ditemukan di kota Wuhan China dan menyebar ke berbagai negara di dunia termasuk di Indonesia. Lembaga kesehatan dunia WHO menetapkan Covid-19 menjadi pandemi (Abdillah, 2020).

Pada 2 Maret 2020, Presiden Jokowi mengumumkan bahwa seorang ibu berusia 64 tahun dan anaknya berusia 31 tahun sebagai penderita pertama Covid-19. Presiden Jokowi menjelaskan keduanya terinfeksi dari warga negara Jepang yang sedang berlibur ke Indonesia. Kasus pertama tersebut diduga berawal dari pertemuan perempuan 31 tahun itu dengan warga negara Jepang yang masuk ke wilayah Indonesia. Pertemuan itu terjadi di sebuah klub dansa di Jakarta pada 14 Februari 2020 .

Semua media massa baik cetak maupun daring memberitakan kasus pertama Covid-19 di Indonesia. Tidak ketinggalan Kompas.com dan Tribunnews.com. Penulis tertarik meneliti berita Kompas.com dan Tribunnews.com. Kedua media daring ini masuk dalam peringkat lima portal berita teratas menurut Alexa.com tahun 2019.

Selain menduduki peringkat atas, Kompas.com dan Tribunnews.com adalah media di bawah satu grup usaha yakni Kompas Gramedia. Penulis menduga, meski keduanya di bawah satu grup usaha, namun memiliki perbedaan dalam cara memberitakan kasus pertama Covid-19 di Indonesia. Pengemasan berita Tribunnews.com menggunakan teknik memancing klik (clickbait) untuk menarik perhatian pembaca (Mardliyah, 2018). Berdasarkan latar belakang di atas, penelitian ini memiliki masalah: bagaimanakah konstruksi berita Covid-19 di Kompas.com dan Tribunnews.com?

Jurnalistik dipahami sebagai proses peliputan, penulisan, dan penyebarluasan informasi (aktual) atau berita melalui media massa. Secara ringkas, jurnalistik bisa diartikan sebagai "memberitakan sebuah peristiwa" (Romli, 2012). Saat ini jurnalistik daring merupakan bentuk baru dari kegiatan jurnalistik. Jurnalistik daring ini mempunyai peluang penyampaian berita yang cakupannya jauh lebih luas daripada jurnalistik konvensional bahkan tak terbatas oleh ruang dan waktu.

Jurnalistik daring sendiri biasa disebut sebagai cyber journalism, jurnalistik internet, dan jurnalistik web yang kini merupakan generasi baru dari jurnalistik konvensional dan jurnalistik penyiaran. Kini, jurnalistik juga berlaku di internet ataupun online sehingga menjadi ilmu baru yang bernama jurnalistik daring (online 
journalism) (Bahri, 2019). Ciri dari sebuah jurnalistik daring yaitu sebagai praktik jurnalistik yang sangat mempetimbangkan berbagai format media untuk menyusun berbagai isi liputan menjadi interaksi antara jurnalis dengan audiens dan juga berbagai elemen berita dengan sumber-sumber online yang lainnya (Romli, 2012).

Menurut Berger dan Luckman (dalam Yoedtadi dkk, 2020). Realitas tidak dibentuk secara ilmiah, dan bukan diturunkan oleh Tuhan, tetapi dibentuk dan dikonstruksi oleh tiap individu. Dengan demikian realitas dapat bermacam-macam. Setiap orang bisa mempunyai konstruksi yang berbeda-beda atas suatu realitas. Setiap orang mempunyai pengalaman, preferensi, pendidikan tertentu dalam menafsirkan realitas sosial itu dengan konstruksinya masing-masing (Eriyanto dalam Yoedtadi dkk, 2020).

Pekerjaan jurnalis pada dasarnya adalah mengkonstruksi realitas, sebab jurnalis menyerap peristiwa-peristiwa untuk kemudian disiarkan menjadi berita. Isi media adalah hasil para jurnalis mengkonstruksikan berbagai realitas yang dipilihnya (Sobur dalam Yoedtadi dkk, 2020). Jurnalis menyusun realitas dari berbagai peristiwa yang terjadi hingga menjadi cerita atau wacana yang bermakna. Pembuatan berita oleh jurnalis pada dasarnya adalah penyusunan realitas-realitas hingga membentuk sebuah cerita atau wacana yang bermakna (Hamad dalam Yoedtadi dkk, 2020).

Framing media dipahami sebagai struktur konseptual atau perangkat kepercayaan yang mengorganisir pandangan politik, kebijakan, wacana, dan menyediakan kategori-kategori standar untuk mengapresiasi realitas. Melalui analisis framing dapat diketahui bagaimana pesan diartikan sehingga dapat diinterpretasi secara efisien. (Ronda, 2018). Dalam komunikasi, framing digunakan untuk membedah cara atau ideologi media saat mengkonstruksi fakta. Framing juga digunakan untuk mengetahui bagaimana cara pandang wartawan atau media dalam mengorganisir, menyeleksi, menulis dan menempatkan suatu isu dalam media. (Ronda, 2018).

Eriyanto (2009) menyebutkan bahwa analisis framing yang menjadi pusat perhatian adalah pembentukan pesan dari teks. Framing melihat bagaimana pesan/ peristiwa dikonstruksi oleh media. Bagaimana wartawan mengkonstruksi peristiwa dan menyajikannya kepada masyarakat (Anggoro, 2014)

\section{Metode Penelitian}

Penelitian ini menggunakan pendekatan deskriptif kualitatif. Menurut Bungin (2007), pendekatan kualitatif adalah suatu proses penelitian yang berdasarkan pada metodologi yang menyelidiki suatu fenomena sosial dan manusia. Untuk mengetahui konstruksi berita Kompas.com dan Tribunnews.com peneliti menggunakan metode analisis framing model Robert N. Entman. Framing menurut Entman dibangun dengan empat cara, yakni define problems/pendefinisian masalah, diagnose causes/mencari penyebab masalah, treatment recommendation/menekankan penyelesaian, make moral judgment/keputusan moral (Entman, 1993).

Dalam metode pengumpulan data penulis menggunakan data primer dan sekunder. Pada data primer peneliti mengambil masing-masing lima berita dari kedua portal media tersebut tentang berita covid-19 pada tanggal 2 Maret 2020. Untuk data sekunder diperoleh dengan studi pustaka mengenai analisis framing, menggunakan referensi buku, jurnal, serta laporan penelitian terdahulu untuk menjadi pedoman penulisan bagi peneliti dalam melakukan olah data. 
Objek penelitian ini adalah konstruksi berita Covid-19 di Kompas.com dan Tribunnew.com. Subjek penelitian adalah berita-berita Covid-19 pada tanggal 2 Maret 2020 di Kompas.com dan Tribunnews.com. Pilihan tanggal publikasi 2 Maret 2020 dengan alasan pada tanggal tersebut untuk pertama kalinya Presiden Joko Widodo mengumumkan penderita pertama Covid-19 di Indonesia.

Berikut ini alur pemikiran analisis framing penelitian ini:

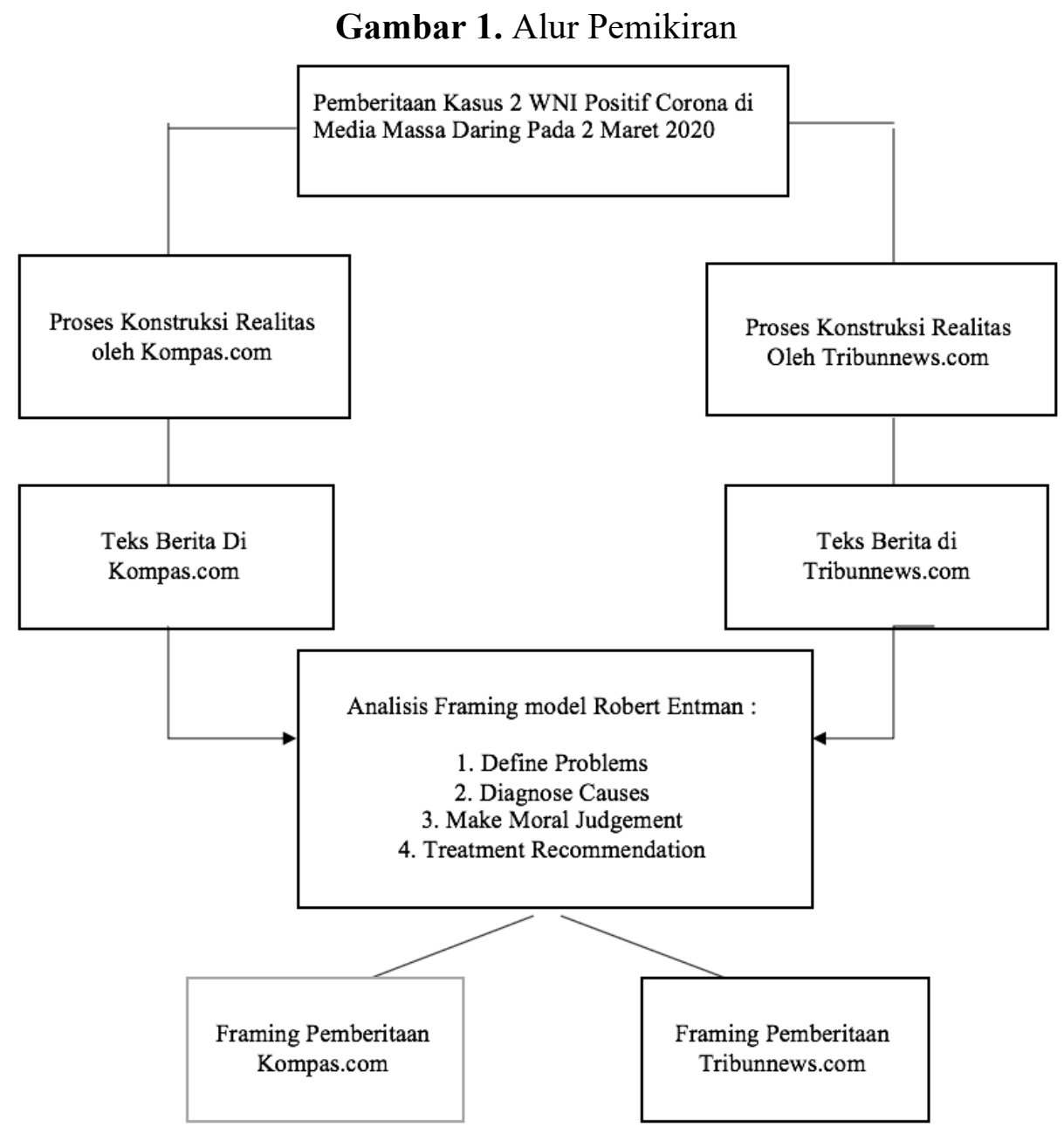

\section{Hasil Penelitian dan Pembahasan}

Penulis memilih masing-masing lima artikel berita dari Kompas.com dan Tribunnews.com pada tanggal 2 Maret 2020.

Tabel 1. Berita Kompas.com

\begin{tabular}{|c|l|c|}
\hline No & \multicolumn{1}{|c|}{ Judul Berita } & Tanggal Terbit \\
\hline 1. & $\begin{array}{l}\text { Dua WNI Positif Corona, Masyarakat Diminta } \\
\text { Jangan Panik Dan Tetap Waspada }\end{array}$ & 2 Maret 2020 \\
\hline 2. & $\begin{array}{l}\text { Istana Bantah Dugaan Pemerintah } \\
\text { Sembunyikan Kasus Penularan Virus Corona di } \\
\text { Indonesia }\end{array}$ & 2 Maret 2020 \\
\hline 3. & $\begin{array}{l}\text { Ridwan Kamil Imbau Warga Yang Alami } \\
\text { Gejala Mirip Virus Corona Segera Periksa }\end{array}$ & 2 Maret 2020 \\
\hline
\end{tabular}


Helen Nurhayati, M. Gafar Yoedtadi: Konstruksi Berita Covid-19 di Kompas.com dan Tribunnews.com

\begin{tabular}{|c|l|c|}
\hline 4. & $\begin{array}{l}\text { Insan Pers Di Imbau Tak Umbar Sensasi Dari } \\
\text { Korban Virus Corona }\end{array}$ & 2 Maret 2020 \\
\hline 5. & $\begin{array}{l}\text { Kasus Pertama Virus Corona, Menkominfo } \\
\text { Minta Masyarakat Cerdas Pilih Informasi }\end{array}$ & 2 Maret 2020 \\
\hline
\end{tabular}

Tabel 2. Berita Tribunnews.com

\begin{tabular}{|c|c|c|}
\hline No & Judul Berita & Tanggal Terbit \\
\hline 1. & $\begin{array}{l}\text { Mengapa WN Jepang Yang Tularkan Virus } \\
\text { Corona Tak Terdeteksi Pemeriksaan Kesehatan? } \\
\text { Ini Kata Menkes }\end{array}$ & 2 Maret 2020 \\
\hline 2. & $\begin{array}{l}2 \text { WNI Terinfeksi Virus Corona, Politikus PDIP } \\
\text { Ini Minta Identitasnya Di Buka }\end{array}$ & 2 Maret 2020 \\
\hline 3. & $\begin{array}{l}\text { WN Jepang Tulari } 2 \text { WNI Positif Corona Bisa } \\
\text { Lolos Bandara? Beda Pendapat Terawan Dan } \\
\text { Pihak Bandara }\end{array}$ & 2 Maret 2020 \\
\hline 4. & $\begin{array}{l}\text { Kronologi Dua WNI Positif Corona, Tertular WN } \\
\text { Jepang, Sempat Tinggal Serumah Di Depok }\end{array}$ & 2 Maret 2020 \\
\hline 5. & $\begin{array}{l}\text { Menkes Terawan Ungkap } 2 \text { WNI Positif Virus } \\
\text { Corona dan WN Jepang Ternyata Punya } \\
\text { Hubungan Dekat. }\end{array}$ & 2 Maret 2020 \\
\hline
\end{tabular}

\section{Frame Kompas.Com: Memberi kepercayaan pemerintah dan menenangkan masyarakat}

Kompas.com dalam menampilkan berita terlihat lebih banyak mengambil sudut pandang pemerintah. Kompas.com memberi kepercayaan kepada pemerintah yang selalu memberikan himbauan kepada masyarakat untuk tetap waspada terhadap Covid-19. Hal ini terlihat jelas dari bagian pendefinisian masalah (define problems), pada lima berita yang diteliti seluruhnya menampilkan himbauan pemerintah.

Pada bagian penyebab masalah (diagnose causes), Kompas.com lebih menonjolkan bahwa penyebab permasalahan ini berasal dari WN Jepang yang bisa lolos masuk ke Indonesia karena berstatus orang tanpa gejala (OTG) sehingga tidak terdeteksi. Hal ini terlihat dari kutipan berita Kompas.com berikut:

Menurut Jokowi, warga Jepang itu baru terdeteksi virus corona setelah meninggalkan Indonesia. Dia dideteksi saat berada di Malaysia. Setelah mendapat kabar itu, pemerintah kemudian melakukan pemeriksaan terhadap seorang ibu dan putrinya. "Dicek dan tadi pagi saya dapat laporan dari Pak Menkes bahwa ibu ini dan putrinya positif corona, " tutur Presiden.

Selanjutnya pada elemen membuat keputusan moral (make moral judgement) Kompas.com mengedepankan nasihat kesehatan agar pembacanya lebih waspada terhadap gejala Covid-19. Hal ini terlihat pada kutipan Kompas.com berikut: 
Gubernur Jawa Barat Ridwan Kamil mengimbau masyarakat yang mengalami gejala seperti virus corona untuk segera memeriksakan diri ke rumah sakit rujukan utama di 27 kabupaten dan kota di Jabar.

Pada elemen menekankan penyelesaian (treatment recommendation) pada Kompas.com dalam menyelesaikan masalah selalu memberi himbauan kepada pembaca jika mempunyai gejala mirip covid-19 segera periksa kerumah sakit dan Kompas.com juga mengingatkan pada akhir elemen penyelesaian masalah agar para awak media untuk tidak mengumbar sensasi dari korban Covid-19.

\section{Frame Tribunnews.com: Pemerintah lalai dan menyalahkan korban Covid-19.}

Pada pendefinisian masalah (define problems) Tribunnews.com menyalahkan pemerintah yang seakan-akan "kecolongan" karena tidak dapat mendeteksi Covid-19 pada WNA Jepang. Hal itu terbaca pada berita berjudul "WN Jepang Tulari 2 WNI Positif Corona Bisa Lolos Bandara? Beda Pendapat Terawan Dan Pihak Bandara". Isi berita tersebut menonjolkan pendapat Menteri Terawan dan ketidaksiapan petugas bandara Soekarno Hatta dalam melakukan deteksi penderita Covid-19.

Sementara pada elemen penyebab masalah (diagnose cause), Tribunnews.com terkesan menyudutkan dua pasien WNI terjangkit Covid-19, karena menerima WN Jepang tersebut di rumahnya dan mengabaikan kewaspadaan ancaman Covid-19. Berikut kutipan berita:

Menteri Terawan Agus Putranto mengatakan bahwa dua pasien positif corona melakukan close contact dengan WN Jepang sehingga beberapa minggu setelah bertemu WN Jepang tersebut di rumahnya, kedua pasien ini terlihat menimbulkan gejala seperti, batuk dan demam.

Sedangkan pada keputusan moral (make moral judgement), Tribunnews.com cenderung mengolah sensasi dan mengembangkan asumsi tak berdasar. Hal ini terlihat dari judul berita "Menkes Terawan Ungkap 2 WNI Positif Virus Corona dan WN Jepang Ternyata Punya Hubungan Dekat". Hubungan dekat hanyalah asumsi yang dikembangkan Tribunnews.com demi mendapatkan sensasi, hal ini terlihat dalam tubuh berita berikut ini:

Relasi dua WNI dengan WN Jepang yang terinfeksi corona tersebut, menurut Terawan, adalah Teman Dekat. "Orang Jepangnya datang ke rumah, lalu dua orang ini mengeluhkan batuk pilek biasa"

Tribunnews.com pada elemen menekankan penyelesaian (treatment recommendation) lebih menonjolkan unsur sensasi pada korban Covid-19 dengan cara membuat berita yang "Clickbait" terlihat dari berita ke empat yang berjudul "Kronologi Dua WNI Positif Corona, Tertular WN Jepang, Sempat Tinggal Serumah Di Depok". Dalam berita ini penulis melihat unsur Clickbait. Clickbait merupakan manipulasi sisi kognitif manusia yang disebut curiosity gap atau yang disebut perbedaan rasa ingin tahu. Dimana judul beritanya memberikan referensi yang memancing rasa ingin tahu para pembaca sehingga mereka terdorong untuk mengklik tautan tersebut untuk mengisi rasa penasarannya (Mardliyah, 2018). 
Kata "tinggal serumah" adalah asumsi yang dibangun oleh Tribunnews.com, karena dalam tubuh berita tidak ditemukan sedikitpun fakta WNI pasien Covid-19 dan WN Jepang tinggal serumah. Peneliti telah menelusuri lebih lanjut soal kasus hubungan dua WNI tersebut dari berita BBC News. Pengakuan dua WNI yang terjangkit covid19 adalah mereka tidak mengenal dekat dengan WN Jepang yang terjangkit, bahkan mereka hanya bertemu sekali dalam acara dansa di suatu klub di Jakarta.

\section{Kesimpulan}

Berita-berita Kompas.com pada 20 Maret 2020 lebih banyak mengambil sudut pandang pemerintah yang selalu memberikan himbauan kepada masyarakat untuk tetap waspada terhadap Covid-19. Frame yang dibangun oleh Kompas.com adalah Covid-19 harus diwaspadai oleh masyarakat, namun pemerintah tengah berusaha melakukan antisipasi secara optimal.

Sementara Tribunnews.com cenderung mengemas berita-berita clickbait. Terbukti dari beberapa berita Tribunnews yang lebih menonjolkan unsur sensasi, tidak berlandaskan empati dengan mengabaikan sudut pandang dua WNI korban pertama Covid-19. Sementara frame yang dibangun oleh Tribunnews.com, bahwa Indonesia "kecolongan" karena tidak dapat mendeteksi secara dini WNA penderita Covid-19. Virus Corona menyebar sebagai akibat kelalaian masyarakat yang melakukan kontak sosial dengan WNA. Framing Tribunnews menyudutkan pasien Covid-19.

\section{Daftar Pustaka}

Abdillah, L. (2020). Stigma Terhadap Orang Positif COVID-19. In T. Limbong,Pandemik COVID-19: Antara Persoalan dan Refleksi di Indonesia (pp. 11- 24). Medan: Yayasan Kita Menulis.

Anggoro, A. D. (2014). Media, Politik dan Kekuasaan (Analisis Framing Model Robert N. Entman tentang pemberitaan hasil pemilihan Presiden, 9 Juli 2014 di TV One dan Metro TV ). Jurnal Aristo. 2(2).

Bahri, A. N. (2019). Diktat Jurnalistik Online. Sumatera Utara: Universitas Islam Negeri.

Bungin, B. H. (2007). Penelitian Kualitatif : Komunikasi, Ekonomi, Kebijakan Publik, dan Ilmu social. Jakarta: Kencana Prenama Media Group.

Entman, R. (1993). Framing: Toward clarification of a fractured paradigm. Journal of Communication (43) 4.

Hooker et al. (2012). Journalists views about reporting avian influenza and a potential pandemic: a qualitative study. Influenza and Other Respiratory Viruses. 6(3), 224-229.

Klemm et al. (2016) Swine flu and hype: a systematic review of media dramatization of the H1N1 influenza pandemic. Journal of Risk Research, 19 (1):1-20.

Prakarsa, T. (2016). Kebijakan Kesehatan Di Tingkat Global, Nasional Dan Daerah. Buku Panduan Jurnalis Isu Kesehatan, 10-26.

Romli, A. S. (2012). Jurnalistik Online: Panduan Mengelola Media Online. Bandung: Nuansa Cendikia.

Ronda, Mirza A. (2018). Tafsir Kontemporer Ilmu Komunikasi. Tangerang: PT. Indigo Media. 
Vol. 4, No. 2, Oktober 2020, Hal $243-250$

World Health Organization. (2005). Outbreak Communication: Best Practices For Communicating for the Public During an Oubreak. Singapore: WHO.

Yoedtadi, Gafar; Loisa, Riris; Sukendro, Genep; Oktaviani, Roswita; Savitri, Lusia. (2020). Tantangan Jurnalisme Damai di Wilayah Pasca Konflik. Jurnal Penelitian Komunikasi dan Opini Publik. 24 (1) 